\title{
Organic Compounds Assessed in Neuse River Water Used for Public Supply near Smithfield, North Carolina, 2002-2005
}

\begin{abstract}
Organic compounds studied in a U.S. Geological Survey (USGS) assessment of water samples from the Neuse River and the public supply system for the Town of Smithfield, North Carolina, generally are manmade and include pesticides, gasoline hydrocarbons, solvents, personal-care and domestic-use products, disinfection by-products, and manufacturing additives. Of the 277 compounds assessed, a total of 113 compounds were detected in samples collected approximately monthly during 2002-2005 at the drinking-water intake for the town's water-treatment plant on the Neuse River. Fifty-two organic compounds were commonly detected (in at least 20 percent of the samples) in source water and (or) finished water. The diversity of compounds detected suggests a variety of sources and uses, including wastewater discharges, industrial, agricultural, domestic, and others. Only once during the study did an organic compound concentration exceed a human-health benchmark (benzo[a]pyrene). A human-health benchmark is a chemical concentration specific to water above which there is a risk to humans; however, benchmarks were available for only 18 of the 42 compounds with detected concentrations greater than 0.1 microgram per liter. On the basis of this assessment, adverse effects to human health are assumed to be negligible.
\end{abstract}

\section{Introduction}

An investigation by the U.S. Geological Survey (USGS) National Water-Quality Assessment (NAWQA) Program characterized the occurrence of 277 organic compounds in Neuse River source water and finished water near Smithfield, North Carolina (fig. 1). About 1,200 square miles of the Neuse River Basin are upstream from the intake at the Smithfield Water Treatment Plant that serves the town of Smithfield, (population $11,900)$. The area includes forested (63 percent of the area), agricultural (about 16 percent), and urban areas (about 14 percent), all of which can potentially affect source-water quality. In addition, major dischargers in the Neuse River Basin of the greater Triangle Area (population estimate 800,000 ) are permitted to per day of treated wastewater upstream from the Smithfield intake (Deamer, 2009).

Samples were collected from the Neuse River approximately monthly between November 2002 and December 2003 and between June 2004 and August 2005, and included 17 sourcewater samples and 13 paired source- and finished-water samples. Source water is streamwater collected at a surface-water intake prior to water treatment, and finished water is water that has passed through treatment processes prior to distribution. The samples were analyzed for pesticides and selected pesticide degradates, solvents, gasoline hydrocarbons, disinfection by-products, personal-care and domesticuse products, and other compounds. discharge more than 160 million gallons

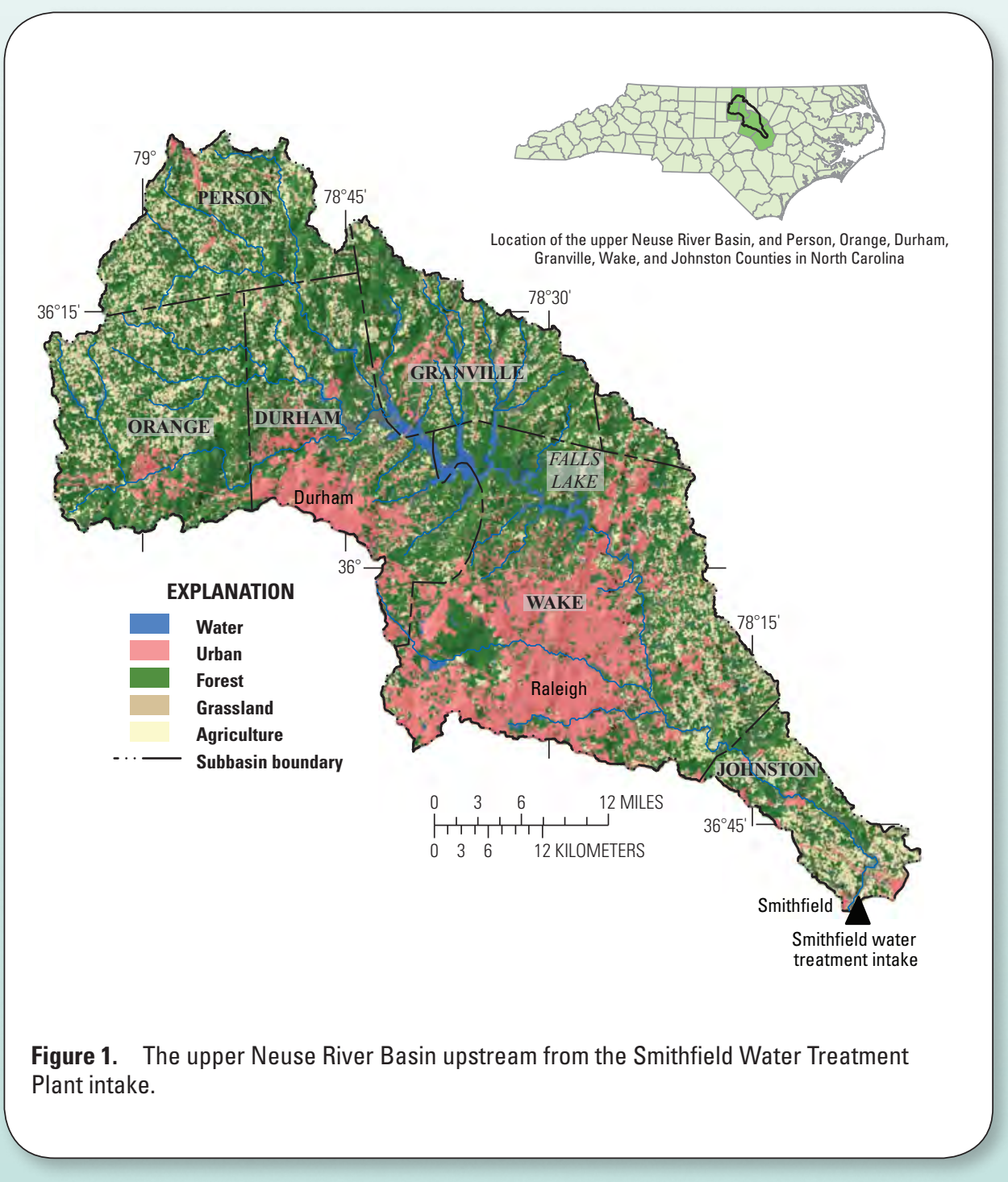


Community water systems are required to monitor finished water for compounds regulated under the U.S. Environmental Protection Agency (USEPA) Safe Drinking Water Act (U.S. Environmental Protection Agency, 1996). Most of the compounds included in this study, however, were not regulated under the USEPA Safe Drinking Water Act.

The Neuse River study is part of an ongoing NAWQA investigation of community water systems across the United States. Detailed information and references on the sampling design, methodology, specific compounds monitored, and the national study were described by Carter and others (2010). Additional information on water quality in the Neuse River Basin is available in a companion study on the occurrence of organic wastewater compounds in selected surface-water supplies (Giorgino and others, 2007).

\section{Occurrence of Organic Compounds, 2002-2005}

Of the 277 compounds tested, 113 compounds were detected in source-water or finished-water samples collected from the Neuse River near Smithfield during 2002-2005, although most contaminants were detected at low concentrations - often 100 to 1,000 times lower than drinking-water standards (see inset). In total, 52 compounds were detected in at least 20 percent of the source-water or finished-water samples (table 1). These compounds included 4 disinfection by-products, 8 gasoline hydrocarbons and oxygenates, 1 fungicide, 15 herbicides and herbicide degradation products, 7 insecticides and insecticide degradation products, 5 manufacturing additives, 5 personal-care and domestic-use products, 4 plant- or animal-derived biochemicals, and 3 solvents. Six compounds were commonly detected (in at least 20 percent of the samples) in source water but were not detected in finished water, including benzene, tert-butyl alcohol, 3,4-dichlororaniline, diazinon, fipronil, and fipronil sulfone (table 1).
Table 1. Commonly detected compounds in source and finished water.

[AHTN, Acetyl hexamethyl tetrahydro-naphthalene; ESA, Metolachlor ethane sulfonic acid; HHCB, Hexahydrohexa-methylcyclopenta-benzopyran; NP2EO, Nonylphenol diethoxylate (total)]

\begin{tabular}{lcc}
\hline \multirow{2}{*}{ Compound } & \multicolumn{2}{c}{ Percent detection } \\
\cline { 2 - 3 } & $\begin{array}{c}\text { Source } \\
\text { water }\end{array}$ & $\begin{array}{c}\text { Finished } \\
\text { water }\end{array}$ \\
\hline \multicolumn{3}{c}{ Disinfection by-products } \\
\hline Chloroform & 97 & 100 \\
Bromodichloro-methane & 0 & 100 \\
Dibromochloro-methane & 0 & 100 \\
Bromoform & 0 & 92 \\
\hline \multicolumn{3}{c}{ Fungicide } \\
\hline Myclobutanil 13 \\
\hline \multicolumn{2}{c}{ Gasoline Hydrocarbons } \\
\hline m- \& p-Xylene & 3 \\
o-Xylene & 3 & 92 \\
\hline
\end{tabular}

\begin{tabular}{|c|c|c|}
\hline \multirow{2}{*}{ Compound } & \multicolumn{2}{|c|}{ Percent detection } \\
\hline & $\begin{array}{l}\text { Source } \\
\text { Water }\end{array}$ & $\begin{array}{c}\text { Finished } \\
\text { Water }\end{array}$ \\
\hline \multicolumn{3}{|c|}{ Insecticide and insecticide degradates } \\
\hline Desulfinylfipronil & 50 & 53 \\
\hline Fipronil sulfide & 53 & 40 \\
\hline Desulfinylfipronil amide & 22 & 27 \\
\hline Carbaryl & 38 & 7 \\
\hline Fipronil & 84 & 0 \\
\hline Diazinon & 59 & 0 \\
\hline Fipronil sulfone & 25 & 0 \\
\hline \multicolumn{3}{|c|}{ Manufacturing additives } \\
\hline $\begin{array}{l}\text { Tri(2-chloroethyl) } \\
\text { phosphate }\end{array}$ & 72 & 75 \\
\hline $\begin{array}{l}\text { Tris(dichlorisopropyl) } \\
\text { phosphate }\end{array}$ & 52 & 67 \\
\hline Tributyl phosphate & 34 & 58 \\
\hline $\begin{array}{l}\text { Tri(2-butoxyethyl) } \\
\text { phosphate }\end{array}$ & 28 & 25 \\
\hline Triphenyl phosphate & 24 & 17 \\
\hline \multicolumn{3}{|c|}{ Personal-care products } \\
\hline HHCB & 79 & 69 \\
\hline Caffeine & 64 & 63 \\
\hline AHTN & 58 & 38 \\
\hline NP2EO & 27 & 19 \\
\hline $\begin{array}{l}\text { Triethyl citrate (ethyl } \\
\text { citrate) }\end{array}$ & 24 & 19 \\
\hline \multicolumn{3}{|c|}{ Plant- or animal-derived biochemicals } \\
\hline Cholesterol & 54 & 25 \\
\hline beta-Stigmastanol & 39 & 17 \\
\hline 3-beta-Coprostanol & 36 & 17 \\
\hline beta-Sitosterol & 21 & 8 \\
\hline \multicolumn{3}{|c|}{ Solvents } \\
\hline Carbon tetrachloride & 0 & 77 \\
\hline Tetrachloroethene (PCE) & 33 & 23 \\
\hline p-Cresol & 27 & 15 \\
\hline
\end{tabular}

\section{Finished-Water Sampling, Water Treatment, and Significance of Comparisons to Source Water}

Finished-water samples were collected at the Smithfield Water Treatment Plant approximately 48 hours after source-water samples were collected to account for treatment-plant retention time of the water (G. Watkins, Town of Smithfield, oral commun., 2003). The Smithfield Water Treatment Plant uses conventional water treatment processes: pre-oxidation with potassium permanganate; coagulation/flocculation using aluminum sulfate; sedimentation; filtration through anthracite and sand; and disinfection with chlorine and chloramine. Powdered activated carbon is used occasionally to treat for taste and odor issues. Some differences between source and finished water may result from the removal of certain organic compounds during treatment; however, many of the compounds studied do not respond to conventional water treatment. Other differences between source- and finished-water quality could be a result of sample timing, variations in retention time, and variability in laboratory sample analysis associated with assessing low concentrations (Kingsbury and others, 2008). Some organic compounds detected in source water may have been removed or transformed during the treatment process into compounds that were not monitored as part of this study.

The study sampling design and resulting comparisons are not intended to characterize treatment efficacy but to provide an indication of the relation of organic compounds found in source water to the quality of finished water. In general, conventional treatment is not specifically designed to remove most of the organic compounds monitored in this study. 


\section{Human-Health Benchmarks Used in this Assessment}

A screening-level assessment of the potential significance of detected organic compounds to human health was based on a comparison of measured concentrations to available human-health benchmarks. Human-health benchmarks are a chemical concentration specific to water above which there is the possibility of harm or risk to humans. Concentrations of regulated compounds were compared to USEPA maximum contaminant levels (MCLs), and concentrations of unregulated compounds that have USEPA-published toxicity information were compared to USGS health-based screening levels (HBSLs), which were developed in collaboration with the USEPA, New Jersey Department of Environmental Protection, and Oregon Health \& Science University (Toccalino and others, 2007). About one-half of the detected compounds do not have humanhealth benchmarks or adequate toxicity information for evaluating results in a human-health context. The screening-level assessment provides an initial perspective on the potential importance of "manmade" organic compounds in source water; it is not a substitute for a comprehensive risk assessment, which includes many more factors, such as additional avenues of exposure and effects of mixtures of compounds.

An additional 10 compounds commonly detected in source water were not commonly detected in finished water and included compounds from all of the major groups (table 1). Four compounds were detected year round in more than 90 percent of the source-water samples. Three of these compounds included the herbicides metolachlor, prometon, and simazine, which commonly are used for weed control (Gilliom and others, 2006). The other compound detected year round was chloroform, a disinfection by-product that may be attributed to treated wastewater being discharged upstream from wastewater-treatment plants (Kingsbury and others, 2008).

\section{Comparison to Human-Health Benchmarks}

Although the type of conventional water treatment used by the Smithfield water system (which is typical of many systems across the Nation) was not specifically designed to remove most of the 277 organic compounds that were studied, concentrations of most of the tested compounds in finished water generally were less than 0.1 microgram per liter $(\mu \mathrm{g} / \mathrm{L})$ and almost always less than human-health benchmarks. For perspective, reporting limits for drinking water commonly are set through Federal regulations at $0.5 \mu \mathrm{g} / \mathrm{L}$, and water utilities generally are not required to measure below this limit. On the basis of this assessment, adverse effects to human health were negligible (subject to limitations of available human-health benchmarks, see inset).

In this study, 42 of the 277 compounds analyzed were detected at least once in source and (or) finished water at concentrations greater than or equal to $0.1 \mu \mathrm{g} / \mathrm{L}$ (table 2 ). In general, compounds that were detected frequently in concentrations greater than $0.1 \mu \mathrm{g} / \mathrm{L}$, such as the herbicide simazine and the gasoline oxygenate MTBE, have relatively widespread use and physical properties that allow them to persist in the environment (Gilliom and others, 2006; Zogorski and others, 2006). Concentrations of 14 of the 15 regulated compounds did not exceed USEPA maximum contaminant levels (MCLs) for drinking water in any sample (table 2). Concentrations also were less than the USGS health-based screening levels (HBSLs) established for three additional unregulated compounds. Humanhealth benchmarks are not available for the remaining 24 compounds that were detected at concentrations greater than $0.1 \mu \mathrm{g} / \mathrm{L}$ (table 2).

Benzo[a]pyrene exceeded the MCL of $0.2 \mu \mathrm{g} / \mathrm{L}$ in one finished-water sample. A maximum concentration of $0.26 \mu \mathrm{g} / \mathrm{L}$ was detected and was qualified as estimated. Estimated values indicate that identification of the compound is reliable, but the concentration has greater uncertainty than unqualified concentrations for the same compound (Kingsbury and others, 2008). This compound is a semivolatile petroleum hydrocarbon and may have been introduced to treated drinking water by leaching from the lining of water-storage tanks and distribution lines (U.S. Environmental Protection Agency, 2011).

The screening-level assessment also identified compounds at concentrations within 10 times the human-health benchmarks. Only three regulated compounds were detected at concentrations within 10 times the USEPA MCL (table 2). These compounds included the disinfection by-products bromodichloro-methane and chloroform in all finished-water samples and the herbicide simazine in 13 sourcewater and 4 finished-water samples.

An important consideration in assessing the potential effects on human health is the common occurrence of mixtures of organic compounds in sourcewater and finished-water samples. For example, the median number of compounds detected in source-water samples from the Neuse River at Smithfield was 23, which was comparible to findings from eight other community water systems assessed by the USGS (see sidebar; Kingsbury and others, 2008). The potential human-health effects of mixtures of organic compounds are largely unknown. The effect of one compound on another's toxicity may be additive, antagonistic, or synergistic. With a few exceptions for pesticides with common modes of action, human-health benchmarks generally are not available for compound mixtures, so continued research is needed. MCLs and other human-health benchmarks generally are based on toxicity data for individual compounds, and the effects of mixtures of compounds at low levels are not well understood (Gilliom and others, 2006).

\section{Comparisons of Organic Compounds in Source Water and Finished Water, 2004-2005}

During the second phase of sampling in 2004-2005, 16 paired source- and finishedwater samples were collected 48 hours apart; 102 compounds were detected, including 71 compounds in at least one source-water sample and 77 compounds in at least one finished-water sample. Comparisons made during this study between paired source-water and finished-water samples are not intended to characterize treatment efficacy, but to provide an indication of which compounds found in source water may be present in finished water prior to distribution (see inset).

Unaffected compounds: Forty-six organic compounds, including several herbicides, personal-care and domestic-use products, and manufacturing additives, were found in paired samples of source-water and finished-water, which indicated that treatment did not affect these compounds (fig. 2).

Personal-care and domestic-use products: The intake for the Smithfield water-treatment plant is located downstream from six municipal wastewater-discharge facilities. Personalcare and domestic-use products were some of the most frequently detected compounds in this study and in a regional study of organic wastewater compounds (Giorgino and others, 2007). Personal-care products, including acetyl hexamethyl tetrahydro-naphthalene (AHTN) and hexahydrohexa-methylcyclopenta-benzopyran (HHCB), are synthetic musks that are known endocrine disruptors. The domestic-use product caffeine is a nonprescription stimulant found in many beverages and over-the-counter medications. In the Giorgino and others (2007) regional study of organic wastewater compounds, these compounds were frequently detected at sites located downstream from municipal wastewaterdischarge facilities and (or) developed land, and the most frequent detections were in the Neuse River at Smithfield.

Manufacturing additives: The detected manufacturing additives were flame retardants 
Table 2. Compounds detected at concentrations greater than 0.1 microgram per liter.

$[\mu \mathrm{g} / \mathrm{L}$, microgram per liter; MCL, maximum contaminant level; HBSL, health-based screening level; ESA, ethane sulfonic acid; OA, oxanilic acid; MTBE, methyl tert-butyl ether; --, no data; E, estimated; ND, not detected at a concentration greater than $0.1 \mu \mathrm{g} / \mathrm{L}]$

\begin{tabular}{|c|c|c|c|c|c|c|c|c|}
\hline \multirow[t]{2}{*}{ Name of compound } & \multicolumn{2}{|c|}{$\begin{array}{c}\text { Number of } \\
\text { samples } \\
\text { analyzed }\end{array}$} & \multicolumn{2}{|c|}{$\begin{array}{l}\text { Percent detection } \\
>0.1 \mu \mathrm{g} / \mathrm{L}\end{array}$} & \multirow{2}{*}{$\begin{array}{l}\text { Reporting } \\
\text { level }{ }^{1}(\mu \mathrm{g} / \mathrm{L})\end{array}$} & \multirow{2}{*}{$\begin{array}{l}\text { MCL } \\
\text { or } \\
\text { HBSL2 } \\
(\mu \mathrm{g} / \mathrm{L})\end{array}$} & \multicolumn{2}{|c|}{$\begin{array}{c}\text { Maximum } \\
\text { concentration } \\
\mu \mathrm{g} / \mathrm{L}\end{array}$} \\
\hline & $\begin{array}{l}\text { Source } \\
\text { water }\end{array}$ & $\begin{array}{c}\text { Finished } \\
\text { water }\end{array}$ & $\begin{array}{l}\text { Source } \\
\text { water }\end{array}$ & $\begin{array}{c}\text { Finished } \\
\text { water }\end{array}$ & & & $\begin{array}{c}\text { Source } \\
\text { water }\end{array}$ & $\begin{array}{c}\text { Finished } \\
\text { water }\end{array}$ \\
\hline \multicolumn{9}{|c|}{ Disinfection by-products } \\
\hline Bromodichloromethane & 30 & 13 & 0 & 100 & 0.03 & & ND & 24.04 \\
\hline Bromoform & 30 & 13 & 0 & 77 & 0.10 & 80 total & ND & 0.43 \\
\hline Chloroform & 30 & 13 & 3 & 100 & 0.02 & THMs $^{3}$ & 0.16 & 43.48 \\
\hline Dibromodichloromethane & 30 & 13 & 0 & 100 & 0.10 & & ND & 7.64 \\
\hline \multicolumn{9}{|c|}{ Fungicide } \\
\hline Pentachlorophenol & 32 & 15 & 6 & 0 & 2.00 & 1.00 & E0.32 & ND \\
\hline \multicolumn{9}{|c|}{ Gasoline hydrocarbons and oxygenates } \\
\hline 1,2,3,5-Tetramethylbenzene & 30 & 13 & 0 & 23 & 0.04 & -- & ND & 0.15 \\
\hline 1,2,4-Trimethylbenzene & 30 & 13 & 3 & 0 & 0.06 & -- & 0.16 & 0.04 \\
\hline Benzene & 30 & 13 & 3 & 0 & 0.02 & 5 & 0.13 & ND \\
\hline Ethylbenzene & 30 & 13 & 0 & 62 & 0.03 & 700 & $\mathrm{ND}$ & 2.09 \\
\hline m- \& p-Xylene & 30 & 13 & 3 & 62 & 0.06 & 10,000 & 0.26 & 8.65 \\
\hline Methyl tert-butyl ether (MTBE) & 30 & 13 & 20 & 0 & 0.10 & -- & E0.3 & 0.05 \\
\hline Naphthalene & 30 & 13 & 0 & 15 & 0.50 & -- & ND & E0.36 \\
\hline o-Xylene & 30 & 13 & 3 & 62 & 0.04 & 10,000 & 0.11 & 7.39 \\
\hline tert-Butyl alcohol & 30 & 13 & 20 & 0 & 0.08 & -- & E0.6 & ND \\
\hline Toluene & 30 & 13 & 3 & 0 & 0.02 & 1,000 & 0.35 & 0.09 \\
\hline \multicolumn{9}{|c|}{ Herbicides } \\
\hline $2,4-\mathrm{D}$ & 32 & 15 & 13 & 13 & 0.04 & 70 & 0.53 & 0.11 \\
\hline Atrazine & 32 & 15 & 6 & 0 & 0.01 & 3 & 0.15 & 0.01 \\
\hline Diuron & 32 & 15 & 6 & 0 & 0.02 & 2 & 0.44 & 0.02 \\
\hline Simazine & 32 & 15 & 41 & 27 & 0.01 & 4 & 0.74 & 0.46 \\
\hline Triclopyr & 32 & 15 & 3 & 0 & 0.03 & 400 & 0.14 & 0.07 \\
\hline \multicolumn{9}{|c|}{ Manufacturing additives } \\
\hline Tri(2-butoxyethyl)phosphate & 29 & 12 & 28 & 25 & 0.50 & -- & 0.62 & E0.5 \\
\hline Tri(2-chloroethyl)phosphate & 29 & 12 & 38 & 67 & 0.50 & -- & E0.26 & E0.22 \\
\hline Tributyl phosphate & 29 & 12 & 7 & 8 & 0.50 & -- & E0.12 & E0.29 \\
\hline Triphenyl phosphate & 29 & 12 & 0 & 8 & 0.50 & -- & ND & E0.16 \\
\hline Tris(dichlorisopropyl)phosphate & 29 & 12 & 14 & 17 & 0.50 & -- & E0.15 & 5.50 \\
\hline \multicolumn{9}{|c|}{ Organic synthesis compound } \\
\hline Anthraquinone & 30 & 13 & 3 & 0 & 0.50 & -- & E0.11 & ND \\
\hline \multicolumn{9}{|c|}{ Pavement- and combustion-derived compounds } \\
\hline Benzo[a]pyrene & 28 & 12 & 0 & 8 & 0.5 & 0.2 & ND & E0.26 \\
\hline \multicolumn{9}{|c|}{ Personal-care and domestic-use products } \\
\hline 4-n-Octylphenol & 33 & 16 & 0 & 6 & 1.00 & -- & ND & E0.25 \\
\hline Acetyl hexamethyl tetrahydro-naphthalene (AHTN) & 33 & 16 & 0 & 6 & 0.50 & -- & ND & E0.3 \\
\hline Caffeine & 33 & 16 & 3 & 0 & 0.02 & -- & E0.12 & ND \\
\hline Hexahydrohexa-methylcyclopenta-benzopyran & 33 & 16 & 48 & 44 & 0.50 & -- & E0.23 & E0.3 \\
\hline Menthol & 33 & 16 & 3 & 0 & 0.50 & -- & E0.16 & ND \\
\hline Nonylphenol diethoxylate (total) (NP2EO) & 33 & 16 & 27 & 19 & 5.00 & -- & $\mathrm{E} 4.3$ & E5.9 \\
\hline Octylphenol diethoxylate (total) (OP2EO) & 33 & 16 & 9 & 6 & 1.00 & -- & E0.16 & E0.24 \\
\hline Octylphenol monoethoxylate (total) (OP1EO) & 33 & 16 & 9 & 6 & 1.00 & -- & E0.63 & E0.44 \\
\hline \multicolumn{9}{|c|}{ Plant- or animal- derived biochemicals } \\
\hline 3-beta-Coprostanol & 28 & 12 & 36 & 17 & 2.00 & -- & E1.4 & E0.7 \\
\hline beta-Sitosterol & 28 & 12 & 21 & 8 & 2.00 & -- & E1.8 & E0.93 \\
\hline beta-Stigmastanol & 28 & 12 & 39 & 17 & 2.00 & -- & $\mathrm{E} 2$ & E1.6 \\
\hline Cholesterol & 28 & 12 & 54 & 25 & 2.00 & -- & E1.6 & E0.91 \\
\hline \multicolumn{9}{|c|}{ Solvents } \\
\hline Acetone (2-propanone) & 28 & 12 & 0 & 8 & 6.00 & 6,000 & ND & E1.33 \\
\hline Carbon tetrachloride & 28 & 12 & 0 & 50 & 0.06 & 5 & ND & 0.3579 \\
\hline p-Cresol & 28 & 12 & 4 & 0 & 1.00 & -- & E0.39 & ND \\
\hline
\end{tabular}

${ }^{1}$ Reporting level shown is higher value of either source- or finished-water.

${ }^{2} \mathrm{MCL}$ values in bold.

${ }^{3} \mathrm{MCL}$ of 80 is for total THMs (trihalomethanes), including chloroform, bromoform, bromodichloromethane, and dibromochloromethane. 


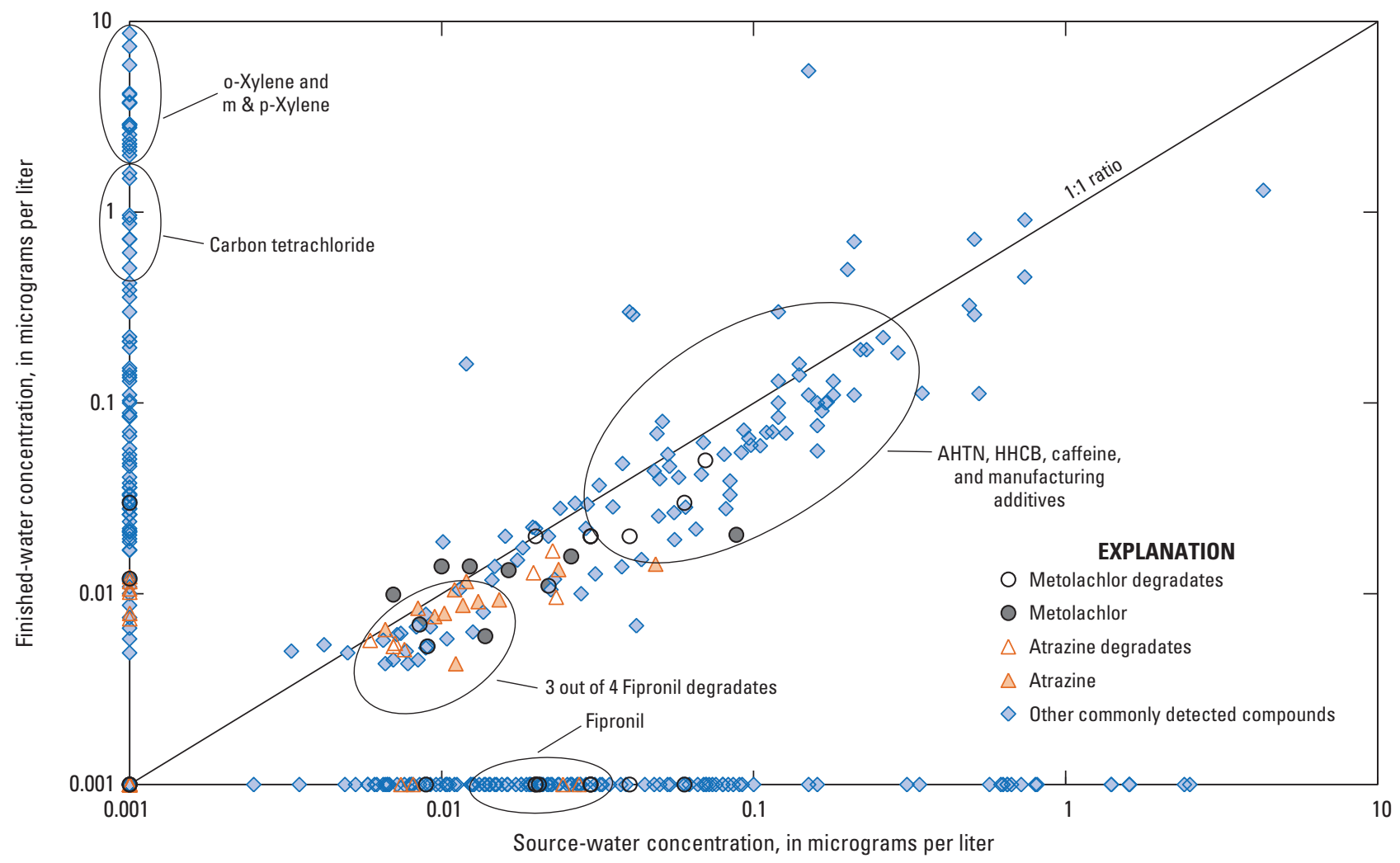

Figure 2. Scatterplot of commonly detected compound concentrations for paired samples of source and finished water.

and plasticizers, which are suspected endocrine disruptors. In the Giorgino and others (2007) regional study of organic wastewater compounds, these compounds were detected frequently at all monitored sites, and the most frequent detections were in the Neuse River at Smithfield. Flame retardants are ubiquitous and can be transported in both urban dust and water (Giorgino and others, 2007).

Herbicides: The percentages of detections and concentrations of many herbicide parent and degradate compounds were similar in source and finished water (fig. 2). Herbicide degradation is attributed mainly to microbial activity in the soils rather than water treatment (Gilliom and others, 2006). The degradates metolachlor ethane sulfonic acid (ESA) and metolachlor oxanilic acid were detected at concentrations 10 times greater than their parent metolachlor concentrations in most samples, whereas atrazine degradates were detected at concentrations similar to their parent atrazine concentrations (fig. 2). These differences can be attributed to the herbicides' properties. Atrazine is chemically more stable, which allows it to persist longer in the hydrologic system than metolachlor, which tends to break down more quickly in the soil zone (Gilliom and others, 2006).
Removed, reduced, or transformed compounds: Twenty-five paired compounds, including many of the insectides and some herbicides and fungicides, were detected only in the source-water paired samples, which indicated that they were removed, reduced, or transformed during the treatment process.

Insecticides: Decreased detections of the insecticides fipronil, diazinon, and carbaryl in finished water may have been a result of degradation or transformation associated with disinfection treatment (Valder and others, 2008). Three of the four fipronil degradates-fipronil sulfide, desulfinylfipronil, and desulfinylfipronil amide-were found in finished-water samples, yet the parent compound fipronil was not found (fig. 2).

\section{Introduced or elevated} compounds: Thirty-one compounds, including disinfection by-products, carbon tetrachloride, and gasoline hydrocarbons, were present only in finished-water paired samples, which indicated that they were introduced during the treatment process.

Disinfection by-products:

Three disinfection by-productsbromodichloromethane, bromoform, and dibromochloromethane-were present only in finished water. The other disinfection by-product, chloroform, was found in all source- and finishedwater paired samples, but chloroform concentrations were three orders of magnitude greater in finshed-water samples. The presence of disinfection by-products in finished water is well understood and regulated and is an expected result of drinking-water disinfection. The source of low-level detections of the solvent carbon tetrachloride in finished-water samples may have been the chlorine that was used for disinfection (Christman, 1980) or possibly a disinfection by-product (Krasner and others, 2006).

Gasoline Hydrocarbons: These compounds are common ingredients in gasoline and other petroleum products and should not be introduced in the watertreatment process. A water-storage basin at the Smithfield water-treatment plant was painted during 2004-2005 and may have been the source of several volatile gasoline hydrocarbons, including o-Xylene and $\mathrm{m}$ - and $\mathrm{p}$-Xylene that were found only in finished-water samples (fig. 2). Gasoline hydrocarbons are commonly present in solvents and paints. 


\section{Source Water-Quality Assessments Conducted Across the Nation as Part of the NAWOA Program}

Beginning in 2002, the USGS initiated the Source Water-Quality Assessment (SWQA) Program as part of the NAWQA Program to characterize the quality of source water used for supply at selected community water systems across the United States (Delzer and Hamilton, 2007). The long-term goal of the SWQA Program was to complete as many as 30 assessments by 2012 at systems that withdraw water from streams, using standard protocols and nationally consistent methods (U.S. Geological Survey, variously dated).

This fact sheet highlights findings from the Neuse River study, which was one of the first nine community water systems assessed as part of the SWQA Program. The fact sheet serves as a companion product to USGS Data Series 544 and USGS Scientific Investigations Report 2008-5208, which present findings for nine systems across the United States (Carter and others, 2010; Kingsbury and others, 2008, respectively).

\section{Neuse River Findings in a National Context and Possible Implications}

Overall, the organic compounds commonly detected in water from the Neuse River (tables 1,2) are among those most commonly detected in ambient streamwater and groundwater across the Nation (Gilliom and others, 2006; Zogorski and others, 2006). The occurrence and concentrations of organic compounds in source- and finished-water samples collected from the Neuse River were similar to those detected at other community water systems that were assessed, many of which have upstream wastewater facilities and drain considerable agricultural and urban land use (Kingsbury and others, 2008). Continued research is needed to better understand sources, transport mechanisms, trends, fate in the environment, and possible links of these compounds to human health.

The USGS continues to collaborate with and complement the work of other Federal, State, and local agencies and organizations, and communicate findings, implications of the results, and future needs, including the following:

- Increased emphasis on watershed management and source-water protection strategies to help minimize the sources and transport of organic compounds to source water and finished water;

- Continued research to enhance toxicity information for commonly occurring unregulated organic compounds and mixtures that are commonly detected in source water and finished water; and

- Monitoring and assessment to identify organic compounds not typically monitored in source water but commonly present in finished water, which may ultimately identify or lead to the development of treatment technologies for use in their removal.

\section{References Cited}

Carter, J.M., Kingsbury, J.A., Hopple, J.A., and Delzer, G.C., 2010, Concentration data for anthropogenic organic compounds in groundwater, surface water, and finished water of selected community water systems in the United States, 2002-10: U.S. Geological Survey Data Series 544, $36 \mathrm{p}$.
Christman, R.F., 1980, Chemistry of the use of chlorine in water and food processing in Jolley, R.L., Brungs, W.A., and Cumming, R.B., eds., Water chlorination, environmental impact and health effects: Ann Arbor, Michigan, Ann Arbor Science Publishers, Inc., v. 3, 1171 p.

Deamer, N. 2009. Neuse River Basinwide Water Quality Plan. N.C. Dept. of Environment and Natural Resources Division of Water Quality Planning section - Basinwide Planning Unit. 496 p., accessed March 9, 2011, at http://h2o.enr. state.nc.us/basinwide/Neuse/2008/documents/ NRBasinwidePlan-Final.pdf/.

Delzer, G.C., and Hamilton, P.A., 2007, National Water-Quality Assessment ProgramSource Water-Quality Assessments: U.S. Geological Survey Fact Sheet 2007-3069, $2 \mathrm{p}$.

Gilliom, R.J., Barbash, J.E., Crawford, C.G., Hamilton, P.A., Martin, J.D., Nakagaki, Naomi, Nowell, L.H., Scott, J.C., Stackelberg, P.E., Thelin, G.P., and Wolock, D.M., 2006, The quality of our Nation's waters-Pesticides in the Nation's streams and ground water, 1992-2001: U.S. Geological Survey Circular 1291, 172 p.

Giorgino, M.J., Rasmussen, R.B., and Pfeifle, C.M., 2007, Occurrence of organic wastewater compounds in selected surface-water supplies, Triangle Area of North Carolina, 2002-2005: U.S. Geological Survey Scientific Investigations Report 2007-5054, 28 p.

Kingsbury, J.A., Delzer, G.C., and Hopple, J.A., 2008, Anthropogenic organic compounds in source water of nine community water systems that withdraw from streams, 2002-05: U.S. Geological Survey Scientific Investigations Report 2008-5208, 66 p.

Kolpin, D.W., Skopec, M., Meyer, M.T., Furlong, E.T., and Zaugg, S.D., 2004, Urban contribution of pharmaceuticals and other organic wastewater contaminants to streams dur ing differing flow conditions: Science of the Total Environ $\neg$ ment, v. 328 , p. $119-130$.

Krasner, S.W., Weinberg, H.S., Richardson, S.D., Pastor, S.J., Chinn, Russell, Sclimenti, M.J., Onstad, G.D., and Thurston, A.D., Jr., 2006, Occurrence of a new generation of disinfection byproducts: Environmental Science \& Technology, v. 40, no. 23, p. 7175-7185.
Lee, K.E., Barber, L.B., Furlong, E.T., Cahill, J.D., Kolpin, D.W., Meyer, M.T., and Zaugg, S.D., 2004, Presence and distribution of organic wastewater compounds in waste $\neg$ water, surface, ground, and drinking waters, Minnesota, 2000-02: U.S. Geological Survey Scientific Investigations Report 2004-5138, 47 p.

Sando, S.K., Furlong, E.T., Gray, J.L., Meyer, M.T., and Bartholomay, R.C., 2005, Occurrence of organic wastewater compounds in wastewater effluent and the Big Sioux River in the Upper Big Sioux River Basin, South Dakota: U.S. Geological Survey Scientific Investigations Report 2005-5249, 108 p.

Toccalino, P.L., Norman, J.E., Booth, N.L., and Zogorski, J.S., 2007, Health-Based Screening Levels - A tool for evaluating what water-quality data may mean to human health: U.S. Geological Survey, National Water-Quality Assessment Program, accessed June 5, 2008, at http://water.usgs.gov/nawqa/HBSL/.

U.S. Department of Agriculture, 2008, Agricultural Research Service (ARS), Pesticide properties database, accessed March 6, 2008, at http://www.ams.usda.gov/ science/pdp/.

U.S. Environmental Protection Agency, 1996, Safe Drinking Water Act (SDWA): U.S. Environmental Protection Agency, accessed June 1, 2007 at http://water.epa.gov/lawsregs/rulesregs/sdwa/.

U.S. Environmental Protection Agency, 2011, Drinking water contaminants, National Primary Drinking Water Regulations, accessed March 7, 2011, at http://water. epa.gov/drink/contaminants/index.cfm.

U.S. Geological Survey, variously dated, National field manual for the collection of water-quality data: U.S. Geological Survey Techniques of Water-Resources Investigations, book 9, chaps. A1-A9, available online at http://pubs.water.usgs.gov/twri9A/(chapters were originally published during 1997-1999; updates and revisions are ongoing and are summarized at $h t t p: / /$ water.usgs.gov/owq/FieldManual/mastererrata.html).

Valder, J.F., Delzer, G.C., Price, C.V., and Sandstrom, M.W., 2008, Study design and percent recoveries of anthropogenic organic compounds with and without the addition of ascorbic acid to preserve water samples containing free chlorine, 2004 06: U.S. Geological Survey Open-File Report 2008-1226, 85 p.

Zogorski, J.S., Carter, J.M., Ivahnenko, Tamara, Lapham, W.W., Moran, M.J., Rowe, B.L., Squillace, P.J., and Toccalino, P.L., 2006, The quality of our Nation's waters - Volatile organic compounds in the Nation's ground water and drinking-water supply wells: U.S. Geological Survey Circular 1292, 101 p.

\section{By Michelle C. Moorman}

\section{USGS Promotes Public Access to Water-Quality Information}

This fact sheet, additional data and investigations reports, and other information are available on the World Wide Web at http://water.usgs.gov/nawqa/swqa/. Included at this Web site are downloadable data on organic compound occurrence, information on sampling designs and methodology, background on data analyses, and frequently asked questions. Contacts for additional information:

Michelle C. Moorman, U.S.Geological Survey, (919) 571-4013,mmoorman@usgs.gov

Greg Delzer, U.S. Geological Survey, SWQA Coordinator (605) 394-3230, gcdelzer@usgs.gov 